\title{
Starting science in the vernacular. Notes on some early issues of the Philosophical Transactions and the Journal des Sçavans, 1665-1700
}

David Banks

\section{(2) OpenEdition \\ Journals}

Electronic version

URL: http://journals.openedition.org/asp/213

DOI: $10.4000 / a s p .213$

ISBN: 978-2-8218-0408-1

ISSN: $2108-6354$

Publisher

Groupe d'étude et de recherche en anglais de spécialité

\section{Printed version}

Date of publication: 1 March 2009

Number of pages: 5-22

ISSN: 1246-8185

\section{Electronic reference}

David Banks, "Starting science in the vernacular. Notes on some early issues of the Philosophical Transactions and the Journal des Sçavans, 1665-1700», ASp [Online], 55 | 2009, Online since 01 March 2012, connection on 02 November 2020. URL : http://journals.openedition.org/asp/213 ; DOI : https:// doi.org/10.4000/asp. 213

This text was automatically generated on 2 November 2020.

Tous droits réservés 


\title{
Starting science in the vernacular. Notes on some early issues of the Philosophical Transactions and the Journal des Sçavans, 1665-1700
}

\author{
David Banks
}

\section{Introduction}

1 I have come to believe that while synchronic study of a language is obviously possible, consideration of how it has come to be the way it is enhances and informs our understanding of its functions and structures in our contemporary situation. In language learning, the so-called irregularities and problems take on a much less daunting appearance when they can be explained in terms of their historical development. For example, the learner who understands that the "irregular" verbs of English are in fact derived from the "regular" strong verbs of old English is less likely to perceive them as simply an arbitrary list of isolated facts to be learnt by heart. What is true of the language in general is also true, I believe, of specialized language, so that the problems specific to specialized language learning may become less problematical when the way specialized language has developed is understood.

2 This article is a contribution to that understanding; it deals with the beginnings of the scientific research article in the first journals to be published in French and English. For French, the first journal in the field was the Journal des Sçavans, and for English, the Philosophical Transactions. These were both founded in 1665, with the French journal first appearing a couple of months before its English counterpart. Certain aspects of this have already been studied. There are historical accounts, ranging from the academic to the popular, of the founding of the Royal Society, and of the Philosophical Transactions itself (e.g., Lyons 1944, McKie 1960, Johns 2000, Gribbin 2005). These works usually mention the Journal des Sçavans in passing, but for something more substantial it 
is necessary to turn to works in French. Historical accounts of the Journal des Sçavans are less numerous, the most extensive being the now fairly dated Morgan 1928. More recently we have seen the work of Vittu appear $(2002 a, 2002 b, 2005)$. There are also biographies of Henry Oldenburg, the founder of the Philosophical Transactions (e.g., Hall 2002, Bluhm 1960). There are a number of works which deal with these questions within the terms of library studies (e.g., Kronick 1962, 1991, Houghton 1975, Gascoigne 1985, Walker \& Hurt 1990). Of those closer to my own, linguistic, interests, some do so basically in terms of text types (e.g., Gotti 2006) or rhetoric (Gross 1996). Others adopt a sociolinguistic approach (e.g., the much cited Bazerman 1988, Atkinson 1999, Valle 1999). Although I am a strong believer in the importance of social factors in the study of text, my approach is rather different to that used in these books. These authors are using the text to illuminate the social situation; I am interested in the social situation as a causal factor in the creation of texts. These are obviously complementary but different. Probably closest to my own preoccupations is Gross et al. 2002, in that it does attempt a diachronic comparison of scientific texts in different languages. However, the fact that in this book quotations from texts in languages other than English are given only in English translation makes it of limited use.

Since this paper ${ }^{1}$ has the unpretentious aim of simply pointing out a possible new area of study, it will be necessarily simple. It is in many ways a preamble, though I think a necessary preamble, to the study of the development of linguistic features which I hope will follow. I shall start with some background information on the two journals. I shall then give some brief notes on each of the items included in the first issues of each of the journals for the years $1665,1675,1685$, and 1695. I shall end with some first indications of differences in the way these two journals set out to disseminate scientific information, and in the ways in which they developed over the first thirty years of their existence. I will consider the number of pages in each issue, and the length of the items they published, the genres they adopted, the language of the books which were reviewed, and the range of subjects that were covered.

\section{The beginnings}

\subsection{The beginnings of the Journal des Sçavans}

4 The first issue of the Journal des Sçavans appeared on 5 January 1665. It was edited and financed by Denis de Sallo, under the patronage of Colbert (Vittu 2005). It is important to note that this was before the establishment of the Académie Royale des Sciences, which came into being in December 1666, almost two years later. It was the earliest publication of its kind to come into existence, and like the Philosophical Transactions (of which more below) it still exists today.

Le Journal des Savants est sans conteste le plus ancien périodique destiné aux lettres et aux scientifiques et, cas unique, il a conservé son titre original au long d'une publication presque ininterrompue depuis 1665. (Vittu 2002a: 179)

The Journal des Sçavans ran into trouble almost immediately; de Sallo created enemies with his hard-hitting reviews. But perhaps more importantly for what followed, he openly supported the Gallican movement which was in favour of a French church independent of Rome. This antagonized the Church in general and the Jesuits in particular, and the papal nuncio used his influence to have the journal suspended. Its need was however recognised and it was reinstated by the end of the year under a new 
editor, the Abbé Gallois, though de Sallo remained the moving force in the background (Vittu 2002, Morgan 1928).

\subsection{The beginnings of the Philosophical Transactions}

6 The Royal Society received its Royal Charter in 1662. It had two secretaries, one of whom was Henry Oldenburg. He was already the centre of an extensive network of scientific correspondence, which he had probably started to create when he was travelling in Europe as the tutor of Richard Jones. As secretary, his duties included reading to the assembled members letters received, and perhaps more importantly from our point of view, he had to inform those members who were not present of the content of the letters which had been read. Having a printed newsletter was obviously a solution to writing out multiple copies of letters received (Kronick 1962). Moreover, unlike most other members of the Royal Society, Oldenburg was not a wealthy amateur, or virtuoso. He had to make his living, and it is known that he was looking for ways of making money from his extensive correspondence; his idea was to do this by distributing intelligence (that is, news) in the form of a newsletter (Hall 2002). It is probable that both of these factors had some influence on the publication which he eventually produced.

Oldenburg and the members of the Royal Society were also aware of what was happening in France. On 11 January 1665, only six days after its publication in Paris, Oldenburg presented the first issue of the Journal des Sçavans to the members of the Royal Society (Vittu 2002b). Bluhm quotes a letter written in February of that year by Sir Robert Moray to Christiaan Huygens in which he says:

Quant a la Gazette des Scauants, Nous en auons veu un essay; mais on y trouue desia a redire. Vous dites bien que la chose pourra estre utile pourueu qu'on ne las gaste point. Monsieur Oldenbourg nous a fait voir un eschantillon du'un semblable dessein bien plus philosophique, et nous faisons estat de l'y engager, sil se peut faire. Jl ne se meslera pas des choses Juridiques ny Theologiques, mais outre les choses philosophiques qui nous viennent de delà la mer il publiera les experiences, au moins les chefs, qui se sont icy. Mais de ne sera quune fois le mois, an Anglois, et une fois en trois mois en latin. (letter from Sir Robert Moray to Christian Huygens, Feb. 1665, quoted in Bluhm, 1960, 190)

8 The first issue of the Philosophical Transactions appeared on 6 March 1665, and was an immediate success. The Latin version referred to in the letter never, in fact, appeared. However, the journal was to have teething troubles of its own, some of which had nothing to do with Oldenburg or the Royal Society. In 1665 England was at war with the Dutch, which did not help international correspondence, and it was also the year in which the plague struck London; the following year was the year of the Great Fire of London; and in 1667 Oldenburg was imprisoned in the Tower for two months as a suspected spy. However, the journal survived, and went on to become a major scientific publication.

\section{Corpus}

9 In this short pilot study, I shall consider the contents of the two journals in the first thirty years of their existence, and how they developed over that period. For the purpose of the study I have used a mini-corpus (Banks 2005a), made up of the first issue 
of each journal for the years 1665, 1675, 1685 and 1695. I shall look first at the contents of the four issues of the Journal des Sçavans, then those of the four issues of the Philosophical Transactions; I shall then give a brief comparison of the two journals and how they developed over the period.

\subsubsection{Journal des Sçavans, 5 Jan. 1665}

\section{items, of which seven are book reviews, or one might say book notices, since they are} all fairly short. Below are given the titles, followed by notes on the content.

1.

VICTORIS VITENSIS, ET VIGILII

Tapsensis, Prouincice Bisacence Episcoporum opera, Edente R.P. Chisletio, Soc. Iesu Presb. in 4. Diuione.

The first item is a review of a book in Latin. It is an edition of the works of Vitensis and Tapsensis, who lived in the 5th century. The title as printed is the title of the book and its bibliographical details, which since the book is in Latin are also in Latin, though the text of the review is in French. This is also true, mutatis mutandis, of the items that follow.

2.

HENRICI SPELMANI GLOSSARIUM,

continens Latino-barbara, peregrine, obsolete, \& nouatce significationis vocabula, in folio, Londini

This is a review of a book in Latin. The book contains vocabulary which is useful for those who read "corrupt" Latin.

3.

RAGGVAGLIO DI NVOVE OSSERVATIONI,

da Giuseppe Campani. in 12. In Roma.

This review is of a book written in Italian. It concerns a new type of lens and its use in the observation of Saturn and Jupiter. This entry is particularly interesting since, as we shall see below, there is a parallel item in the Philosophical Transactions.

4. DISSERTATIO DE PRÆCEDENTIA

Regum Gallic, Hispanice, \& Anglice : simul \& tractatus de Legatis. Authore Iacobo Hovvel, Anglo, Londini.

14 This is a review of a book in Latin translated from English. The book itself is a book of history whose object is to defend the primacy of English kings. This provokes a highly critical and patriotic review in favour of the French monarchy.

5.

MARTINI SCHOOCKII DE STERNVTATIONE.

Amstelodami.

Again, this is a review of a book in Latin. It is a book of anatomy which deals with the nature of sneezing. It is a new edition of a book originally published fifteen years earlier. The author is said to have completely altered his opinion.

6. GASPARIS SCIOPPII SVSPECTARVM

Lectionum Libri quinque. Amsteldami. 
This is a review of a book in Latin which is an edition of the letters of Scoppius who lived in the $2^{\text {nd }}$ century. The review is highly critical of the Ancients in general, and of Plautus and Apuleius in particular.

7.

L'HOMME DE RENÉ DES CARTES,

auec un traité de la formation du Fœtus du mesme Autheur. A Paris.

17 This is a review of a book in French. It is in fact the posthumous publication of two treatises by Descartes.

8.

EXTRAIT D'VNE LETTRE ESCRITE

d'Oxfort, le 12. Nouembre 1664.

The final item is an extract from a letter written in French from Oxford in England. It concerns the birth (and death) of Siamese twins, and their subsequent autopsy.

\subsubsection{Journal des Sçavans, 2 Jan. 1675}

The issue of the Journal des Sçavans for 2 January 1675 has five items, and like the above has twelve pages of text. The five items are all book reviews.

1.

VINDICIE EPISTOLARVM S. IGNATII

Autore Ioan. Pearson Presbytero Cantabrigice. Prostant Londini. Et se trouvent à Paris chez Frederic Leonard

This is a review of a book in Latin. It concerns the distinction between bishops and priests, and also deals with the authenticity of the letters of St. Ignatius.

2.

SYNDICON ECCLESIÆ PARISIENSIS

Parisiis, apud F. Muguet.

21 The second item is again a review of a book in Latin, and is a collection of synodal statutes.

3.

DE L'ORIGINE DES FONTAINES

A Paris chez Pierre Petit.

This review is of a book in French. It is about the formation of springs. The importance of water and where it comes from made this a significant area of study at this period.

4.

LA VIE DV MARESCHAL DE GASSION,

$\grave{a}$ Paris chez Guillaume de Luyne, au Palais.

This is a review of a French military biography.

5.

NOVVELLES EXPERIENCES DV VVIDE,

avec la description des Machines qui servent à les faire. A Paris chez J. Cusson fils.

24 This review is of a book in French in the area of experimental physics, and concerns the nature of a vacuum. This item is printed in a smaller typeface than the other items in the issue, presumably to fit it in without increasing the number of pages. 


\subsubsection{Journal des Sçavans, 8 Jan. 1685} The issue of the Journal des Sçavans for 8 January 1685 has six items,
book reviews, and is rather shorter having only eight pages of text.

1. OEUVRES DIVERSES D'UN AUTEUR

de sept ans. in 4. à Paris. writings of a child prodigy.

2.

LAURENTIJ J. MOLIN. EXERCITATIO

Academica de Clavibus, etc. in 8. Vpsal. 1684.
27 of keys in antiquity.

3.

ENTRETIENS SUR LES VIES ET

sur les Ouvrages des plus excellens Peintres anciens \& modernes. IV. Partie in 4. à Paris chez SEB. Mabre Cramoisy. 1685.

The third review is of a book in French by a certain Felibien. It is the $4^{\text {th }}$ volume of a series on painters.

4.

THESAURUS ASCETICUS SIVÉ

Syntagma opusculorum 18. à Grcecis olim P P. De re Ascetica scriptorum, nunc primum e vet. Cod. Mss. eruta, Collect. atque interpr. P. Possino S. I. in 4. à Paris chez Ant. Dezallier. 1685.

The fourth review is of a book in Latin. It is a collection of treatises on asceticism by Possines.

5.

EXPERIENCE SINGULIERE D'Angleterre

envoyée à M. Mesmim D. M. par M. Papin D. M. l'un des membres de la societé Royale de Londres.

This item is an extract from a letter written from England by a French member of the Royal Society. It is about a variety of fast-growing lettuces, the downside of the procedure being that the earth in which they grow takes two years to prepare!

6.

NOUVEAUTEZ DU COMMENCEMENT

de l'Année.

31 The final item in this issue is a list of books received. This is presumably the first example of a "books received" rubric in a journal. It is also incomplete and it is said that it will be continued in the next issue, so this may also well be the first example of a "to be continued" in history!

\subsubsection{Journal des Sçavans, 3 Jan. 1695}

The issue of the Journal des Sçavans for 3 January 1695 has ten pages of text, but contains only two items, both of which are book reviews.

1. MEMOIRES POUR SERVIR A L'HISTOIRE

Ecclesiastique des six premiers siecles, justifies par les citations des Auteurs Originaux; avec une Chronologie, \&c. Tome Second. Par le Sieur D.T. In 4. à Paris chez Ch. Robustel. 1694. 

lives of the saints.

2.

FUNDAMENTUM THEOLOGIÆ MORALIS

id est de recto usu opinionum probabilium, in quo ostenditur, ut quis licite posit sequi opinionem probabilem faventem libertati adversus legem, omnino necessarium esse \& sufficere quod post diligentem veritatis inquisitionem, ex sincero desiderio non offendendi Deum susceptam, opinion illa ipsi appareat, attenta ratione \& authoritate, vel unice verisimilis, vel manifeste verisimilior quam opposite, stans pro lege adversus libertatem, ac idcirce $a b$ ipso judicetur vera judicio absolute, firmo \& non fluctuante. Authore R. P. Thyrso Gonzalez, Theologice Professore Salmaticensi, nunc Prœposito Generali Societatis Jesu. In 4. Lugduni. Et se trouve à Paris chez Antoine Dezallier. 1694.

The second item is a review of a book in Latin (with a very long subtitle). It is a treatise of moral theology by Thirse Gonzalez.

It will be noted that overall the contents are mainly book reviews. It covers a wide range of

subjects, and the format changes little over the period. I shall now consider the corresponding issues of the Philosophical Transactions.

\subsubsection{Philosophical Transactions, 6 Mar. 1665}

The very first issue of the Philosophical Transactions appeared on 5 March 1665; it had 16 pages of text, and contained 11 items.

1.

The Introduction.

38 The first item is by way of an editorial, giving the justification of the journal and its objectives.

2.

An Accompt of the improvement of Optick Glasses.

The second item tells of information which has come from Paris about a new book just published in Italy, Ragguaglio di nuoue Osservationi by Guiseppe Campani. This is the same book of which a review appeared as the third item in the first issue of the Journal des Sçavans. It is difficult to tell whether this item is based solely on the entry in the Journal des Sçavans, though as stated above we know it was available in London, or whether other information was available too.

3.

A Spot in one of the Belts of Jupiter.

40 This is a short news item, only 8 lines long, reporting Hooke's observations of the rings of Jupiter.

4.

The Motion of the late Comet proedicted.

41 This is a detailed summary of a published paper by Adrien Azout, entitled "The Ephemerides of the Comet". It had been sent to the secretary (i.e., Oldenburg) with a covering letter.

5.

An Experimental History of Cold.

42 This item tells of a book by Boyle which is in press. The book is entitled "Experiments in order to an Experimental History of Cold". The entry is curious in that it contains a 
list of possible experiments, from which readers are invited to select those which should be carried out.

6.

An account of a very odd Monstrous Calf. account of a deformed foetus calf.

7.

of a peculiar Lead-Ore of Germany, and the Use thereof.

This is a short news item with a request for more information about the mineral in question.

8.

Of an Hungarian Bolus, of the same Effect with the Bolus Armenus.

This is again a short news item, only six lines long, sent by the same person as the previous entry. Bolus is a type of earth. That referred to here has medicinal uses.

9.

of the New American Whale-fishing about the Bermudas.

This is a report from an oral account by "an understanding and hardy Sea-man". In particular, it gives biological details of the whales killed.

10.

A Narrative concerning the success of Pendulum-Watches at Sea for the Longitudes.

47 This item derives from Major Holmes. It is a report on the use of new watches for the determination of longitude. It is claimed that the watches provided better positions than had been expected.

11.

The Character, lately published beyond the Seas, of an Eminent Person, not long since dead at Thoulouse, where he was a Councellor of Parliament.

The final item in this issue is an obituary notice for the famous mathematician, Fermat, and includes a list of his books.

\subsubsection{Philosophical Transactions, 25 Mar. 1675}

The issue of the Philosophical Transactions for 25 March 1675 is rather longer, at 31 pages of text, and contains eight items.

1. INTRODUCTION TO THE Eleventh Year of these TRACTS

This issue also begins with an editorial, but much more detailed than that of 6 March 1665.

2.A more particular Account of the last Eclipse of the Moon, as it was observed by the Parisian Astronomers, and promised by us in our former Numb.111. English't out of the French Journal des Scavants.

51 This second item runs to three and a half pages, and is more like an article. It is a translation of an article which had previously appeared in the Journal des Sçavans, and gives a description of an eclipse with detailed timings.

3.

A Breviate of Monsieur Picarts Account of the Measure of the Earth. 

gives a method for calculating the circumference of the earth, with detailed calculations. The work for the book was carried out by Cassini, Picard and Roemer.

4.

An Extract of the French Journal des Scavans, concerning a New Invention of Monsieur

Christian Hugens de Zulichem, of very exact and portative watches.

53

Again this item is derived from French. It is translated from the Journal des Sçavans. It is a description of a spring-balance watch which had been developed by Huygens. This item sparked off a priority dispute between Hooke, who claimed to have had the initial idea, and Huygens.

5.

An Extract of a Letter, lately written to the Publisher by Dr. Swammerdam, of an unusual Rupture of the Mesentery.

54 This item is printed in Latin, despite the title being in English, and is without translation.

6.

A Letter of Mr. Martin Lister, containing his Observations of the Astroites or Star-stones; communicated to the Publisher Jan. 19.1673/4. ${ }^{2}$

This a letter from Lister, printed verbatim with interpolated remarks by Ray. It is a description of fossils.

7.

An accompt of two Books:

I. Les dix Livres d'Architecture de VITRUVE, corrigez, \& traduits nouvellement en Francois, avec des Notes \& des Figures; par Claude Perrault, de l'Academie Royale des Sciences, \& Medecin de la Faculté de Paris. Imprimé à Paris, 1673. in fol.

The two final items in this issue are book reviews, and it will be noted that they are headed as such, in what may be one of the first attempts to create a specific rubric in a journal of this type. The first review is of the then celebrated treatise on architecture by Vitruvius, who lived in the $1^{\text {st }}$ century $\mathrm{BC}$. The review contains considerable discussion of the translation as such.

8.

II. Anthonii le Grand Dissertatio de Carentia Sensus \& Cognitionis in BRUTIS : Londini, apud Joh. Martyn, R. Soc. Typographum, ad Insigne Campance in Cameterto D. Pauli. 1671.

57 The second book reviewed is also in Latin. It deals with the possibility of knowledge in animals.

\subsubsection{Philosophical Transactions, 28 Jan. 1685}

58

The issue of the Philosophical Transactions for 28 January 1685 is slightly longer again, with 38 pages of text, and it contains 11 items.

1.

Some Experiments about Freezing, and the difference betwixt common fresh Water Ice, and that of Sea Water: also a probable Conjecture about the Original of the Nitre of IIgypt: by Dr. Lister, Fellow of the Royal Society.

59 This item is an article, with an author named and his affiliation given, Lister, Fellow of the Royal Society (FRS). It deals with a series of experiments concerning the freezing of various liquids. 
2.

A Letter from Dr. Turbervile of Salisbury containing some considerable Observations in the Practice of Physic.

This item is a letter, printed verbatim, from Turbervile, and gives three short medical case studies.

3.

Observations on the Cicindela Volans, or Flying Glow-worm, with the figure thereof made, and Designed by Richard Waller Esq. F. of the R.S

61 This item is an article; the author and his affiliation are given, Richard Waller, FRS. The article is a description of an insect. There are untranslated Latin quotes, and the article has footnote references.

4.

A Letter of Mr. John Davis Minister of little Leak in Nottinghamshire to one of the R. S. concerning the Wurtemberg Engine Dated 26th. November. 1684.

\section{translation.}

5.

The Description of a Siphon performing the same things with the Sipho

Wurtemburgicus;invented by Dr. Papin Fellow of the Royal Society.

This item is an article, and like the previous item is printed in Latin without translation. The author is named, Papin, and his affiliation, FRS, is given.

6.

A Miscellaneous Catalogue of Mean, vulgar, cheap and simple Experiments, Drawn up by Sr. William Petty, President of the Dublin Society, and Him presented to that Society

This odd item is a list of 63 experiments to be performed. It ends œwith the words "With infinite more Experiments of this kind". The author and his credentials are given, William Petty, President of the Dublin Society.

7.

A Letter from Mr. J: Beaumont of Stony-Easton in Sommersetshire to one of the S. of the R. S. concerning a New way of Cleaving rocks

This item is an extract from a letter sent to the secretary by J. Beaumont. It describes a method for breaking rocks with gunpowder.

8.

A Discourse proving from Experiments, That the larger the Wheels of a Coach, \&c. are (ceeteris paribus,) the more easily they may be drawn over a Stone or such like obstacle that lies in the way: by a member of the Philosophical Society of Oxford.

This article is anonymous, but the affiliation of the author, the Philosophical Society of oxford, is given. It is experimental in nature and deals with the size of wheels and the effort required to move them. The article has footnote references.

9.

De ORIGINE FONTIUM Tentamen Philosophicum in Prelecttione habita coram Societate Philosophica nuper Oxonice instituta ad Scientiam Naturalem promovendam,. Per Rob. Plot LL. D. Custodice MUSÆI ASHMOLEANI Oxonice Prcepositum. \& REGIE SOCIETATIS Secretarium Oxon. in $8^{\circ} .1685$.

This issue ends with three book reviews, but here there is no apparent attempt to create a rubric. The first review is of a book in Latin dealing with the origin and nature of springs.

10.

Medicina Septentrionalis Collatitia, S. Rei inedica nuperis annis à Medicis Anglis, Germanis 
\& Danis emisse sylloge \& syntaxis. Opera Theophili Boneti. D. M. cum Indicibus \& figures necessaries. Genevce. M. DC. LXXXV. in Fol

The second review is again of a book in Latin dealing with medical problems.

11 .

Johannis Nicolai Pechlini Med. D. P. serenissimi Cimbrice Principis Reg. Archiatri, Theolphilus Bibaculus, sive de Potu Thece Dialogus Francofurti; Quarto, 1684.

The final review is also of a book in Latin which is a description of the tea plant and its uses, including medicinal uses.

\subsubsection{Philosophical Transactions, Jan. $1695^{3}$}

The final issue in this small sample does not have a precise date, but is simply "for the month of January". It has 39 pages of text, and contains 9 items. It will also be noted that in this issue the items are numbered.

1.

I. An Account of the Earthquakes in Sicilia, on the Ninth and Eleventh of January, 1692/3 Translated from an Italian Letter wrote from Sicily by the Noble Vincentius Bonajutus, and Communicated to the Royal Society by the Learned Marcellus Malpighius, Physician to his present Holiness

The first item in this issue is an extract from a letter, and is translated from Italian. The original letter is by Bonajutus, forwarded by Marcello Malpighi. It is relatively long, running to nine pages, and gives a description of an earthquake with lists of populations and casualties.

2.

II. A Letter from Mon' Buissiere, a French Anatomist and Surgeon, concerning an Egg found in the Tuba Fallopiana of a Woman lately dissected; with several Remarks touching Generation.

The second item is a letter printed in French from Buissiere, who was in London at the time. It gives the results of an autopsy carried out on a woman who had been executed.

3.

III. Remarks, taken upon Dissecting the Body of A. M. a Maid of about Thirty Years of Age who dyed of an Ascites, the First of August, 1689.

This item is an autopsy report of a woman who had died of dropsy or oedema. The report is anonymous, but the names of two witnesses who were present are given at the end.

4.

IV. Observatio Casus non vulgaris De Hydrope intra Uteri Tunicas contento.

Despite the Latin title, this item is in English. Like the previous item it is an autopsy report on a woman who had died of dropsy, or oedema, which had incorrectly been diagnosed as hysterical pregnancy. This also is anonymous but the names of four witnesses are given at the end.

5.

V. De Morsu venenoso Canis rabidi.

Again a Latin title, but the report which follows is in English. It concerns a boy who died of rabies.

VI. Solutio Problematis Florentini de Testitudine Veliforme Quadrabili, a Davide Gregorio,

M.D. ac R.S.S. Communicata. 
This item, by Davide Gregorio, is printed in Latin. It is mathematical in nature.

7.

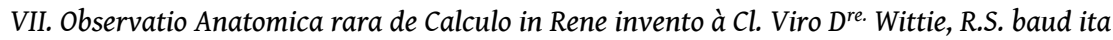
pridem Communicata.

The seventh item is also printed in Latin. It is by Wittie, and concerns kidney stones.

8. An Account of BOOKS.

I. Osservationi Naturali, ove si contengono materie Medico-Fische, \&c. Natural Observations, containing several Medico-Physical and Botanical Matters, with divers Natural Productions, several sorts of Phosphori, Subterraneous Fires in Italy, and other Curious Subjects, in Familiar Letters, by Signior Paul Boccone, M.D. Printed at Bononia in $12^{\circ} 1684$.

The first book reviewed is in Italian. The beginning only of the title is given in Italian, followed by a translation of the complete title. The book is heterogeneous in nature, dealing with 26 miscellaneous subjects.

9.

II. Lezioni intorno alla Natura delle Mosette \&c. Discourses concerning the Nature of Damps,

by Leonardus Capuanus, a Member of the Academy of the Investigantes. Naples, in $4^{\text {to. }} 1683$.

The second book reviewed is also in Italian. Again, only the beginning of the title is given in Italian, followed by the complete title in English. The book contains three lectures about gases, particularly coal gas.

It is interesting to note that in the 1685 issue, each new item begins on a new page; however, this is not the case in the 1695 issue. Overall, there is a narrower range of subjects, but a fairly wide range of genres, with fewer book reviews than the Journal des Sçavans. There is also an increase in the number of pages over time. A further interesting point is that 4 of the items in the 1675 issue have related visuals, 3 in 1685 and 2 in 1695; there are none in the corresponding issues of the Journal des Sçavans.

\section{Some elements of comparison}

81 It is possible to compare the length of issues and of the items they contain. This is done in Table 1.

Table 1. Length of issues and items

\begin{tabular}{|c|c|c|c|c|c|c|}
\hline & \multicolumn{3}{|c|}{ Journal des Sçavans } & \multicolumn{3}{c|}{ Philosophical Transactions } \\
\hline & pages & items & pp./item & pages & items & pp./item \\
\hline 1665 & 12 & 8 & 1.5 & 16 & 11 & 1.5 \\
\hline 1675 & 12 & 5 & 2.4 & 31 & 8 & 3.9 \\
\hline 1685 & 8 & 6 & 1.3 & 38 & 11 & 3.5 \\
\hline 1695 & 10 & 2 & 5.0 & 39 & 9 & 4.3 \\
\hline
\end{tabular}

The Philosophical Transactions has more pages than the Journal des Sçavans. The length of the issues of the Journal des Sçavans remains fairly stable, whereas the length of the Philosophical Transactions more than doubles over this period, with the biggest increase being between the first and second year. The average length of items is the same in the first issues of the two journals; it is longer in the Philosophical Transactions for the issues of the years 1675 and 1685. The items in the Journal des Sçavans for the 1695 are slightly longer than those in the corresponding issue of the Philosophical Transactions, but it will be noted that this issue of the Journal des Sçavans contains only two items. 
It is also possible to compare the genres used in the two journals. This is done in Table 2. It is true that some of the borderlines are greyish, but the general picture which this provides remains correct.

Table 2. Genres

\begin{tabular}{|l|c|c|c|c|c|c|c|c|}
\hline & \multicolumn{4}{|c|}{ Journal des Sçavans } & \multicolumn{4}{c|}{ Philosophical Transactions } \\
\hline & 1665 & 1675 & 1685 & 1695 & 1665 & 1675 & 1685 & 1695 \\
\hline $\begin{array}{l}\text { Book } \\
\text { review }\end{array}$ & 7 & 5 & 4 & 2 & - & 2 & 3 & 2 \\
\hline $\begin{array}{l}\text { Letter or } \\
\text { extract }\end{array}$ & 1 & - & 1 & - & 2 & 2 & 3 & 2 \\
\hline Article & - & - & - & - & 1 & 2 & 4 & 5 \\
\hline News item & - & - & - & - & 6 & - & - & - \\
\hline Obituary & - & - & - & - & 1 & - & - & - \\
\hline Editorial & - & - & - & - & 1 & 1 & - & - \\
\hline $\begin{array}{l}\text { Book } \\
\text { extract }\end{array}$ & - & - & - & - & - & 1 & - & - \\
\hline List & - & - & 1 & - & - & - & 1 & - \\
\hline
\end{tabular}

The Journal des Sçavans has a more restricted range of genres than the Philosophical Transactions. It concentrates mainly on book reviews, which account for 18 of its 21 items (86\%). In the Philosophical Transactions, with a total of 39 items, 12 (31\%) are articles, albeit some of them rather embryonic; nine (23\%) are letters, or extracts from letters. So, these two constitute the major genres. Book reviews, which provide seven items $(18 \%)$ is here a minor genre. The importance of news items in the first issue (six of the 11 items) can also be noted. Gotti (2006) considers that the epistolary form has a particularly important role to play in the development of the experimental article in these early issues of the Philosophical Transactions.

It is also interesting to note the languages of the books reviewed. These are given in Table 3. Latin is the commonest language which appears: ten of eighteen in the case of the Journal des Sçavans, and four of seven in the case of the Philosophical Transactions. However, in the Journal des Sçavans, French comes a close second, with seven books reviewed, and only one in Italian; whereas in the Philosophical Transactions two Italian books are reviewed, and only one in French. It can also be noted that whereas in the Journal des Sçavans all the items (in the journal as a whole) are in French, in the Philosophical Transactions there are four items in Latin and one in French.

Table 3. Language of books reviewed

\begin{tabular}{|c|c|c|c|c|c|c|}
\hline & \multicolumn{3}{|c|}{ Journal des Scavans } & \multicolumn{3}{c|}{ Philosophical Transactions } \\
\hline & Latin & French & Italian & Latin & French & Italian \\
\hline 1665 & 5 & 1 & 1 & - & - & - \\
\hline 1675 & 2 & 3 & - & 1 & 1 & - \\
\hline 1685 & 2 & 2 & - & 3 & - & - \\
\hline 1695 & 1 & 1 & - & - & - & 2 \\
\hline
\end{tabular}

Finally, it is interesting to note the subjects treated in these early issues of the two journals. This is done in Table 4. The categories here are those that might be used today. While this means that it is sometimes difficult to determine the precise nature of the subject in modern terms in some cases (Gascoigne 1985), the table nevertheless gives us a broad picture of the journals in question. 
Table 4. Subjects treated

\begin{tabular}{|l|c|c|c|c|c|c|c|c|}
\hline & \multicolumn{5}{|c|}{ Journal des Sçavans } & \multicolumn{3}{c|}{ Philosophical Transactions } \\
\hline & 1665 & 1675 & 1685 & 1695 & 1665 & 1675 & 1685 & 1695 \\
\hline Astronomy & 1 & - & - & - & 3 & 1 & - & - \\
\hline $\begin{array}{l}\text { Medicine/ } \\
\text { Anatomy }\end{array}$ & 3 & - & - & - & 1 & 1 & 2 & 5 \\
\hline Biology & - & - & - & - & 2 & - & 1 & - \\
\hline Geology & - & 1 & - & - & 2 & 2 & 1 & 1 \\
\hline Physics & - & 1 & - & - & 1 & - & 1 & - \\
\hline Agriculture & - & - & 1 & - & - & - & - & - \\
\hline Chemistry & - & - & - & - & - & - & 1 & 1 \\
\hline Technology & - & - & - & - & 1 & 1 & 3 & - \\
\hline Botany & - & - & - & - & - & - & 1 & - \\
\hline Mathematics & - & - & - & - & - & - & - & 1 \\
\hline Art & - & - & 1 & - & - & 1 & - & - \\
\hline Philosophy & - & - & - & - & - & 1 & - & - \\
\hline Classics & 2 & - & - & - & - & - & - & - \\
\hline Language & 1 & - & - & - & - & - & - & - \\
\hline History & 1 & - & 1 & 1 & - & - & - & - \\
\hline Religion & - & 2 & 1 & 1 & - & - & - & - \\
\hline Biography & - & 1 & - & - & - & - & - & - \\
\hline Literature & - & - & 1 & - & - & - & - & - \\
\hline Bibliography & - & - & 1 & - & - & - & - & - \\
\hline Varia & - & - & - & - & 1 & 1 & 1 & 1 \\
\hline
\end{tabular}

It can be seen that the Philosophical Transactions is mainly restricted to what would now be thought of as scientific subjects, whereas the contents of the Journal des Sçavans is spread over a much wider area. In the Journal des Sçavans, the most common subject is Religion, which accounts for $19 \%$ of the items. This is followed by Medicine and History, which account for $14 \%$ each. Classics accounts for a further $10 \%$. In the case of the Philosophical Transactions, Medicine is the most common subject accounting for $23 \%$ of the items. This is followed by Geology, accounting for 15\%, and Technology, $13 \%$. Astronomy (and Varia) account for 10\%. The Philosophical Transactions has no items at all in the areas of Religion, History, or Classics. Of the items in the Journal des Sçavans, 33\% might be said to be in the scientific area, whereas this would be true of $85 \%$ of the items in the Philosophical Transactions.

While this short study is based on a restricted sample, it provides an interesting picture, and shows that further study of the early issues of these two journals will be fruitful. As a linguist working within a systemic functional framework, I would find it interesting to see how the transitivity patterns in terms of processes and participants, thematic structure and its progression (Halliday 2004, Banks 2005b and 2008), and evaluation and appraisal strategies (Martin \& White 2005) are encoded and develop over time in the early issues of these journals. Other linguistic approaches, and indeed other subdisciplines will no doubt see other, equally interesting, lines of enquiry. 


\section{BIBLIOGRAPHY}

Atkinson, Dwight. 1999. Scientific Discourse in Sociohistorical Context, The Philosophical Transactions of the Royal Society of London, 1675-1975. Mahwah, NJ: Lawrence Erlbaum.

Banks, David. 2005a. "The case of Perrin and Thomson: An example of the use of a mini-corpus". English for Specific Purposes 24/2: 201-211.

Banks, David. 2005b. Introduction à la linguistique systémique fonctionnelle de l'anglais. Paris: L'Harmattan.

Banks, David. 2008. The Development of Scientific Writing, Linguistic features and Historical Context. London: Equinox.

Bazerman, Charles. 1988. Shaping Written Knowledge, The genre and activity of the experimental article in science. Madison, WI: University of Wisconsin Press.

Bluhm, R. K. 1960. “Henry Oldenburg, F.R.S. (c.1615-1677)”. In Hartley, Harold (ed.). The Royal Society. Its origins and founders. London: The Royal Society, 183-197.

Gascoigne, Robert Mortimer. 1985. A Historical Catalogue of Scientific Periodicals, 1665-1900. With a survey of their development. New York: Garland.

Gribbin, John. 2005. The Fellowship, The Story of a revolution. London: Allen Lane.

Gotti, Maurizio. 2006. "Disseminating early modern science: specialized news discourse in the Philosophical Transactions”. In Brownlees, Nicholas (ed.). News Discourse in Early Modern Britain. Bern: Peter Lang, 41-70.

Gross, Alan G. 1996. The Rhetoric of Science. $2^{\text {nd }}$ edn. Cambridge, MA: Harvard University Press. Gross, Alan G., Joseph E. Harmon and Michael Reidy. 2002. Communicating Science, The scientific article from the $17^{\text {th }}$ century to the present. Oxford: Oxford University Press.

Hall, Marie Boas. 2002. Henry Oldenburg. Shaping the Royal Society. Oxford: Oxford University Press. Halliday, M. A. K. (revised Christian M.I.M. Matthiessen). 2004. An Introduction to Functional Grammar. $3^{\text {rd }}$ edn. London: Arnold.

Houghton, Bernard. 1975. Scientific Periodicals. Their historical development, characteristics, and control. London: Clive Bingley.

Johns, Adrian. 2000. "Miscellaneous methods: authors, societies and journals in early modern England". British Journal for the History of Science 33/2, 159-186.

Kronick, David A. 1962. A History of Scientific and Technical Periodicals. The origins and development of the scientific and technological press, 1665-1790. New York: Scarecrow Press.

Kronick, David. 1991. Scientific and Technical Periodicals of the Seventeenth and Eighteenth Centuries: A guide. Metuchen, NJ: Scarecrow Press.

Lyons, Henry. 1944. The Royal Society 1660-1940. A history of its administration under its charters. Cambridge: Cambridge University Press.

Martin, J. R. \& P. R. R. White. 2005. The Language of Evaluation. Appraisal in English. Basingstoke, GB: Palgrave Macmillan.

McKie, Douglas. 1960. “The origins and foundation of the Royal Society of London”. In Hartley, Harold (ed.). The Royal Society. Its origins and founders. London: The Royal Society, 1-37. 
Morgan, Betty Trebelle. 1928. Histoire du Journal des Sçavans depuis 1665 jusqu'en 1701. Paris: Presses Universitaires de France.

Valle, Ellen. 1999. A Collective Intelligence, The life sciences in the Royal Society as a scientific discourse community, 1665-1965. Turku, Finland: AnglicanaTurkuensia.

Vittu, Jean-Pierre. 2002a. "La formation d'une institution scientifique : Le Journal des Savants de 1665 à 1714. Premier article : D'une entreprise privée à une semi-institution”, Journal des Savants, janvier-juin 2002, 179-203.

Vittu, Jean-Pierre. 2002b. "La formation d'une institution scientifique : Le Journal des Savants de 1665 à 1714. Second article : L'instrument central de la République des Lettres”, Journal des Savants, juillet-décembre 2002, 347-377.

Vittu, Jean-Pierre. 2005. “Du Journal des Savants aux mémoires pour l'histoire des science et des beaux-arts : l'esquisse d'un système européen des périodiques savants”. XVII siècle 228, 527-545

Walker, Richard D. and C. D. Hurt. 1990. Scientific and Technical Literature. An introduction to forms of communication. Chicago: American Library Association.

\section{NOTES}

1. An earlier version of this paper was presented at the Congrès de la SAES, Orléans 2008.

2. At this period, some people were using a calendar in which the year began in March. Hence this date would be 1673 for those using the old calendar, but 1674 for those using the calendar which like ours has the year begin in January.

3. The volume I am here calling "Jan. 1695" for convenience was in fact published "for the month of January 1694". The precise date is not given. Material for the year 1965 was not easily available at the time of carrying out this research.

\section{ABSTRACTS}

The Journal des Sçavans and the Philosophical Transactions were both founded in 1665, and went on to become major journals both of which still exist. They both also had difficulties in the years immediately following their creation. This study is based on a mini-corpus for the years 1665-1695. It indicates that over this period the Journal de Sçavans changed little; book reviews constituted the majority of the items printed, the number of pages remained more or less the same, but at the same time it covered a wide range of subjects. In comparison, the Philosophical Transactions covered a narrower range of subjects, mainly those we would now think of as being scientific; however, it used a wider range of genres, with relatively few book reviews; and the number of pages increased over the period studied.

Le Journal des Sçavans et les Philosophical Transactions ont été fondés tous les deux en 1665, et sont devenus des revues majeures qui continuent d'exister de nos jours. Les deux ont également connu des difficultés dans les premières années de leur existence. Cette étude prend comme base un mini-corpus couvrant la période 1665-1695. Elle suggère que pendant cette période le Journal 
des Sçavans a peu évolué ; les comptes rendus de livres constituaient la majorité des entrées, le nombre de pages était relativement stable, mais en même temps, le Journal traitait une large gamme de sujets. Par comparaison, les Philosophical Transactions traitaient une gamme plus restreinte, principalement les sujets que l'on qualifie de nos jours de scientifiques ; néanmoins cette revue utilisait plus de genres, avec relativement peu de comptes rendus; par ailleurs, le nombre de pages a augmenté pendant la période étudiée.

\section{INDEX}

Mots-clés: compte rendu, discours scientifique, XVIIe siècle, Journal des Sçavans, Philosophical Transactions, revue

Keywords: book review, journal, Journal des Sçavans, Philosophical Transactions, scientific discourse, 17 th century

\section{AUTHOR}

\section{DAVID BANKS}

David Banks is Professor of English Linguistics at the Université de Bretagne Occidentale. He is Director of ERLA (component of EA 4249 - HCTI), and Président of l'Association française de la linguistique systémique fonctionnelle. He has written or edited a dozen books and over 50 academic articles. His main research interest is the analysis of scientific discourse.

David.Banks@univ-brest.fr 